\title{
THE USE OF HERMENEUTICS DOUBLE MOVEMENT FAZLUR RAHMAN IN COMPREHENDING HADITH OF THE UNSUCCESSFUL LEADERSHIP OF WOMEN
}

\author{
Faiq Ainurrofiq \\ Institut Agama Islam Negeri Ponorogo, Indonesia \\ faiqainurrofiq84@gmail.com \\ Article history: \\ Submitted: 09-02-2019 | Revised: 27-08-2019 | Revised: 14-10-2019 | \\ Accepted: 18-11-2019
}

\begin{abstract}
This study examines the hadith about the failure of a nation when led by women. Textually, the meaning of the hadith is contrary to social reality that exhibits the number of women to become leaders in the political sphere. Using the contextual approach of double movement hermeneutics, Fazlur Rahman, this study compares textualist and contextualist methods in interpreting the hadith based on the meaning of the text and the historical, social and political context that underlie the emergence of the hadith. Based on the results of the study, it was found that the cause of a person's inability to be a leader was not because of his gender but because of lacking the capacity to be a leader. It can be found leaders who fail because they do not have leadership capacity, only with popularity, money, and political dynasties, and less capable in leadership. Lastly, this type of leader is addressed by the hadith, not the focus on gender.
\end{abstract}

Keywords: Double Movement Hermeneutics, Leadership Of Women, Gender

\begin{abstract}
Abstrak
Tulisan ini mengkaji hadis tentang tidak akan berhasilnya suatu bangsa jika dipimpin oleh perempuan. Metode yang digunakan adalah dengan mengkomparasikan antara pendekatan tekstualis dan kontekstualis dalam memaknai hadis. Ketika dibaca secara tekstual tampak makna hadis bertentangan dengan realitas sosial yang menunjukkan banyaknya pemimpin perempuan yang kompeten dalam ranah politik. Sebab itu, penulis mencoba menggali makna hadis dengan pendekatan kontekstual hermeneutika double movement Fazlur Rahman. Pertama, penulis berusaha menggali makna teks dan konteks historis, sosial, dan politik yang melatari munculnya hadis. Kemudian ditemukan pesan utama hadis yaitu penyebab ketidakmampuan seseorang untuk menjadi pemimpin bukan karena jenis kelaminnya, namun karena tidak memiliki kapasitas untuk menjadi pemimpin. Seringditemukan pemimpin yang gagal karena pada dasarnya tidak memiliki kapasitas leadership.Banyak yang menjadi pemimpin hanya bermodalkan popularitas, uang, dan dinasti politik, namun kurang cakap dalam kepemimpinan. Menurut penulis, jenis pemimpin seperti inilah yang disasari oleh hadis tersebut, bukan fokus kepada jenis kelaminnya.
\end{abstract}

Kata Kunci: Double Movement Hermenetik, Kepemimpinan Perempuan, Gender 


\section{Introduction}

One popular religious proposition that is considered biased because it limits the women right become leaders is the hadith narrated by $\mathrm{Abu}$ Bakrah which means: It will never be success for a nation to be led by a woman. ${ }^{1}$ It is also used by some mufassir to legitimize the invalidity of women being presidents, governors, regents, judges, and other public sector leaders, as can be found in Tafsir Tematik Kementerian Agama on the topic of women's leadership. ${ }^{2}$ Besides, this hadith is also used as a basis by some scholars to explain certain gender precisely women lower than men. ${ }^{3}$ This hadith is very popular and often used as a reference in various sources when discussing women's leadership. Fatimah Mernissi included the hadith in the category of misogynous traditions that were considered to be deviant. ${ }^{4}$

According to Amin Abdullah, the hadiths deal with political, social, economic, and cultural issues - as well as the hadith narrated by Abi Bakrah - need to be re-analyzed in-depth, and renewal of interpretation, understanding, and interpretation is required. Thus, reinterpretation is necessary to be conducted because the social, economic, cultural, and political situation and institutions at the time of the hadith appear very different from the social, economic, cultural, and political institutions at present. For this reason, efforts are needed to reach the possibilities of new interpretations that are following the Islamic spirit. $^{5}$

The quality of the hadith narrated by Abi

\footnotetext{
1"Abd Allah Muhammad ibn Isma'il al-Bukhari, Shahih alBukhari, Juz 4 (Beirut: Dar al-Fikr, n.d.), 228.

${ }^{2}$ Lajnah Pentashihan Mushaf al-Qur'an, Tafsir al-Qur'an Tematik, vol 3 (Jakarta: Kamil Pustaka, 2014), 46.

${ }^{3}$ Zaitunah Subhan, Al-Qur'an \& Perempuan Menuju Kesetaraan Gender Dalam Penafsiran (Jakarta: Prenanda Media Group, 2015), 93.

${ }^{4}$ Misogynic Hadiths are all reports of behavior, words and provisions based on the Prophet's element of hatred towards women. Ahmad Fudhaili, Perempuan di Lembaran Suci, Kritik atas Hadis-Hadis Shahih (Jakarta: Kementerian Agama RI, 2012), 137.

${ }^{5}$ M. Amin Abdullah, Islamic Studies di Perguruan Tinggi, Pendekatan Integratif-Interkonektif (Yogyakarta: Pustaka Pelajar, 2012), 142.
}

Bakrah is still being debated. Tsuriyah Iqshari, in his study, stated that the hadith is $\underline{d} a{ }^{\prime}$ 'if. It was proven by the weakness in sanad and matan. The weakness in matan was reflected in the contradiction between hadith and al-Qur'an editor, and discord with another hadith, while the gap in sanad lies in Abi Bakrah who are individually denied his witness, besides that there are two rawi who are considered not tsiqqoh, and facts that contradict the history of asbab al-wurud hadis. ${ }^{6}$ Besides, Nur Khoirin was considered that the hadith is $\underline{s} a \underline{h} \underline{i} \underline{h}$. Khoirin quantitatively concluded that this hadith is ahad. Abu Bakrah - ualitatively - is $\underline{s}$ ali $\underline{h}$ and wara', as Ibn Sa'ad appraisal. His pedigree can also be traced, Abu Bakrah has a name Nufi' ibn Masruq. ${ }^{7}$

The two studies contradict in assessing the quality of hadith. However, this study did not focus on the criticism of the hadith, but to compare the two approaches in understanding the hadith with the textual and contextual approaches. Therefore, the purpose of this study was to find out the differences results of the meaning of the hadith on the failure of women's leadership narrated by Abi Bakrah with a textual and contextual approach to the double movement hermeneutic model of Fazlur Rahman. Finally, this study was contextualized with the relevance of hadith to the current socio-political conditions.

Previous research has explored many studies that investigated women's leadership and made the historical hadith of Abu Bakrah as one of worth reviewing; Ida Novianti (2008) which highlights how al-Qur'an provides encouragement for women's equality to take part in all fields so that the hadith that shows the prohibition of women to become leaders needs to be understood

\footnotetext{
${ }^{6}$ Tsuriyah Iqshari, al-Imāmah al-Siyāsiyyah li al-Mar'ah, Dirāsah Naqdiyyah Haditsiyyah (al-Maghrib: Ifriqya asy-Syarq, 2017), 158

${ }^{7}$ Nur Khoirin, Telaah Terhadap Otensititas Hadits-Hadist Misogini (Yogyakarta: Kerjasama Mc Gill Project, Departemen Agama RI, dan IAIN Sunan Kalijaga, 2017), 58-60.See also article Kaizal Bay dan Sri Chalida, "Reinterpretasi Terhadap Pemahaman Hadits-Hadits Tentang Gender Dalam Perspektif Fiqh Al-Hadits," Jurnal Ushuluddin 24, no. 1 (2016): 48.
} 
contextually so as not to conflict with the spirit of the Qur'an. ${ }^{8}$ Husain Hamka's (2013) examined Abu Bakrah's hadith as a justification for the negative image of women who are assumed to be less courageous leaders in supporting programs and making decisions. ${ }^{9}$ Anis Ma'shumah's lift (2012) investigated textual reading of religious texts especially those related to women's leadership so that the results of their interpretation tend to be biased. Regarding the hadith narrated by Abu Bakrah, it was quoted Fatimah Mernissi's opinion-the hadith experienced a deviation and manipulation. ${ }^{10}$

Those studies appeared that understanding of the hadith narrated by Abu Bakrah tends to focus on a particular context point when the hadith was narrated without bringing it to the present context. Even the latest research considered the hadith to be distorted so that it was not worthy of being used as a reference. This study was not intended to justify whether the hadith was distorted and inappropriate context as in previous research, but tried to compare the understanding of the textual and contextualist models. The result of contextualizing the meaning of hadith with the double movement approach led us to the sense that was still relevant to the present condition. Therefore, Fazlur Rahman's double movement approach used in this study.

\section{A Brief Biography and Geneology of Thought of Fazlur Rahman}

Fazlur Rahman was born on September 21, 1919 AD in Hazara, northwest of Pakistan. His father's name was Maulana Syahab al-Din. He grew up in a society that adheres to the Hanafi

\footnotetext{
${ }^{8}$ Ida Novianti, "Dilema Kepemimpinan Perempuan Dalam Islam," Yin Yang 3, no. 2 (2008): 255-261.

${ }^{9}$ Husain Hamka, "Kepemimpinan Perempuan dalam Era Modern," Al-Qalam 19, no. 1 (2016): 107-116.

${ }^{10}$ Lift Anis Ma'shumah, "Teks-teks Keislaman Dalam Kajian Feminisme Muslim: Telaah Metodologis Atas Pandangan Feminis Muslim Terhadap Penciptaan Dan Kepemimpinan Perempuan," Sawwa: Jurnal Studi Gender 7, no. 2 (2012): 67-90.
}

school of thought, which has a more rational style of thinking. Unlike traditionalist parents who feel frightened by modernization that will negatively affect their children's faith and morals, Rahman's father believes that Muslims must place modernization aside as a challenge as well as an opportunity. Rahman himself admitted that the construction of his character formation was greatly influenced by his father and mother. From his mother he learned the values of truth, compassion, loyalty, and love. From his father he learned how Muslims should face modernization. ${ }^{11}$

When Fazlur Rahman was 14 years old (1933 AD), his family moved to Lahore, where Rahman began his modern education. In 1940 AD, Rahman completed his Bachelor's Degree in the Arabic Department at Punjab University. Two years later he obtained a Master of Arts degree at the same department and university. In 1946 AD, Rahman then continued his study in the doctoral program at Oxford University, England with a concentration on the study of Islamic Philosophy. Rahman completed his doctoral study in 3 years (1946-1949) with a dissertation entitled Avicenna's Psychology. ${ }^{12}$

Fazlur Rahman was a liberal-reformative figure who has neo-modernist ideas. Rahman was called liberal-reformative because it carried out opposition to traditional thinking and at the same time reformed conventional Islamic thought in Pakistan. ${ }^{13}$ It was also called neo-modernist because criticized the classical Islamic treasures and Western Orientalist views relating to Islam and Muslims.

For instance, Rahman criticized the orientalists who denied the existence of hadith and doubted the authenticity of al-Qur'an. According to him,

\footnotetext{
${ }^{11}$ Ahmad Syukri Sholeh, Metodologi Tafsir Al-Qur'an Kontemporer dalam Pandangan Fazlur Rahman (Jakarta: Gaung Persada Press, 2007), 19.

${ }^{12}$ Rifki Ahda Sumantri, "Hermeneutika Al-Qur'an Fazlur Rahman Metode Tafsir Double Movement," Komunika: Jurnal Dakwah dan Komunikasi 7, no. 1 (2013): 5.

${ }^{13}$ Abdul Mustaqim, Epistemologi Tafsir Kontemporer (Yogyakarta: eLKIS, 2011), 87.
} 
the prophet is the main figure whose words may not be noticed by his people. Regarding the authenticity of the Qur'an, Rahman considered it has final and does not matter; what needs to be criticized was the understanding of the mufassir on al-Qur'an. ${ }^{14}$

Rahman emphasized that Muslims must investigate the Western world and its ideas critically and objectively to obtain success facing the modern world. Therefore, the role of Muslims today is to develop an appropriate and logical methodology for studying al-Qur'an as guidance for future. The efforts to reform Islamic thought carried out by Rahman includes the interpretation methodology. In this case, according to Rahman Muslim scholars have two obstacles the weak sensitivity of the relevance of al-Qur'an to respond contemporary human needs and concerns of interpretation considered to deviate from the traditional view that has been established and widely accepted. ${ }^{15}$ However, almost all aspects have received extreme resistance from conservative clerics and even he was almost killed. Seeing such conditions Rahman finally moved from Pakistan in 1968 and settled in Chicago, United States until he died in 1988. ${ }^{16}$

Rahman's hermeneutic thinking style included in objective hermeneutics because, in his hermeneutic still recognize the original meaning. According to Mustaqim, Rahman was influenced by the objectivist hermeneutic thinker Emelio Betti. The difference between the two lied in how to dive into the original meaning. Betti argued that the original meaning of a text lied in the author's reason, wherein its interpretation of the text must be brought to the mind of the author. While Rahman considered that it was impossible for a muffasir to enter the mind of the creator of the text, God. The possible thing to do to get original

\footnotetext{
${ }^{14}$ Abdul Mustaqim, 89.

${ }^{15}$ Fazlur Rahman, Tema-tema Pokok al-Qur'an, translated by Erfan Nurtawab and Ahmad Baiquni (Bandung: Mizan, 2017), XVII.

${ }^{16}$ Ibid., 92
}

meaning was to understand the environmental context called asbab an-nuzul macro which can be explored through socio-historical studies. ${ }^{17}$

Rahman appeared to argue with Shah Waliyullah al-Dahlawi to discuss micro and macro. He said that what was asked must first be questioned, the micro and macro compilation of the Qur'an was revealed. Previously al-Dahlawi in his work Fauz al-Kabir fi Ushul al-Tafsir had used the terms asbab nuzul al-khassah and asbab nuzul al-ammah. However, Rahman criticized al-Dahlawi because asbab nuzul al-ammah al-Dahlawi was only limited to examining the socio-broad context without considering its moral ideal and could contextualize it, the interpretation style of al-Dahlawi might be classified in premodernist revivalism that was textually fast. Other similarities are those agreed upon by the Qur'an to respond to the social life of Arab society. ${ }^{18}$

Furthermore, Double movement hermeneutics, Fazlur Rahman, was also influenced by Hans George Gadamer's hermeneutics, which Rahman called a subjective hermeneutic figure. Although Rahman did not recognize the influence, the similarities between Gadamer hermeneutics and double movement Fazlur Rahman found. The equation lied in the existence of pre-understanding that already surrounds the interpreter. Therefore, pre-understanding has preceded mufassir, the objective mufassir was asked to express text messages and to leave pre-understanding by prioritizing the horizon of the text and exploring the historicity of the emergence of the text. Rahman considered that the text has its context to interpret and to understand social settings. In the application stage, Rahman did not use the literal meaning of the text but moral ideal drawn from the text. ${ }^{19}$

Mustaqim included Rahman's hermeneutics

\footnotetext{
${ }^{17}$ Ibid., 176

${ }^{18}$ Kurdi, et.al., Hermeneutika al-Qur'an dan Hadis (Yogyakarta: eLSAQ Press, 2010), 75-76.

${ }^{19}$ Ibid., 78-79.
} 
method into objective hermeneutics because hermeneutics recognized the existence of original meaning. Mawardi embraced Rahman into the hermeneutical class of subjectivists because the subjectivity of mufassir knowledge appeared in the double movement hermeneutics before finally mufassir discovers original meaning by leaving pre-understanding and prioritizing the horizon of the text, exploring the historicity of the emergence of the version.

\section{The Concept of Hermeneutics Double Movement Fazlur Rahman}

Hermeneutics is interpreted literally by interpreting, explaining and translating. Scientists interpret hermeneutics as the process of changing something from a situation of ignorance to being understood, from something abstract and dark to a clear expression that can be understood. Hermeneutics is also interpreted by translating and acting as interpreters. ${ }^{20}$

Based on point of view, the Interpreter was divided into several categories. Abdullah Said in Sahiron Samsyuddin's book divides the interpreter into three. First, textualists are interpreters who rely only on language criteria to determine the meaning of texts. The textualist interpreter follows rigidly and takes the literal meaning. The interpreters are traditionalists and Salafists. Second, semi-textualists, interpreters of this group are the same as the textual categorization; the difference lies in the use of modern idioms in maintaining the literal meaning of the content of the Qur'anic text. The mufassir are neo-revivalist movements, such as al-Ikhwan al-Muslimun in Egypt and the Islamic Jama'at in India. Third, contextualist emphasized the importance of paying attention to the socio-historical context in the process of understanding and interpreting the Qur'anic text and hadith. Political, social, historical, cultural and economic conditions and situations both the time of the Prophet and the time

\footnotetext{
${ }^{20}$ Sahiron Syamsuddin, et.al., Hermeneutika al-Qur'an Mazhab Jogja (Yogyakarta: Islamika, 2003), 54.
}

when the text interpreted were critical to consider. That was done to determine the category of altsawabit (fixed aspects) and al-mutagghayyirat (aspects that can change). Mufassir of this school are Fazlur Rahman, ijtihadi, progressive Muslims and liberal Muslims. ${ }^{21}$

From the category, It can be concluded that Rahman included in the third categorydouble movement hermeneutics to avoid textual interpretation. The procedures of this method are starting from the present, then return to the time the text was revealed, and be drawn back to the present. Through this method, interpretation is expected to be contextual and can be used to answer current problems. ${ }^{22}$

The details of Rahman's double movement hermeneutic practical steps started with the first movement, namely from the present situation to the time the text was passed down. The text (al-Qur'an) revealed because it responded to what Muhammad thought and responded to what happened in the Arabian Peninsula at that time. ${ }^{23}$ The first movement consists of two stages: first, the stage of understanding the meaning of a statement by examining the historical situation or problem in which the text statement was the answer. The context of this situation included micro and macro contexts. The micro context is more directed to a specific situation, while the macro context includes the situation of society, customs, institutions, and even life in the Arabian Peninsula at the time of the descent of the text. The first step of first movement aimed to understand the meaning of the text as a whole as well as within the boundaries of specific teachings as a response to specific situations. Second, generalize specific answers and make statements having general moral-social goal. It filtered from specific texts in light of socio-historical background and

\footnotetext{
${ }^{21}$ Ibid., $52-54$.

${ }^{22}$ Kurdi, et.al., Hermeneutika al-Qur'an dan Hadis, 70.

${ }^{23}$ Fazlur Rahman, Islam and Modernity, Transformation of an Intellectual Tradition (Chicago: The University of Chicago Press, 1982), 5.
} 
ratio legis (illah hukm) that is often stated. ${ }^{24}$

The second movement was the process of general views to specific views to formulate and realize today. The general view is embodied in the present socio-historical context of the congress. It required a deept study of the current situation and analysis of various component elements to assess the current situation and bring it to the present situation as far as is needed to determine new priorities and implement al-Qur'an values or hadith in the present era. ${ }^{25}$

In short, the first step of this method is to explore the meaning of the text compatibility with the context al-Qu'an and hadith revealed. The meaning of the text must be studied chronologically, followed by exploring the general principles of the text through the sociocultural context of Arab society at that time. The second movement was examining the sociological state of contemporary society based on principles of the Qur'an or hadith. ${ }^{26}$

Rahman's double movement theory detects between text, author, and reader. As a reader, Rahman did not force the text according to the needs of the author, but the text explained as it is. To communicate with the text, Rahman examined the historicity of the text. Historical is not merely asbab nuzul or asbab wurud as understood by traditional scholars, led to the descent of the text, included the social setting of the Arab community in which the Qur'an and hadith are revealed qira'ah at-tarikhiyyah. The purpose of the historical study of the text was to look for universal values of the text which Rahman called moral ideals, moral ideals are valid for all time and do not change. ${ }^{27}$

Rahman distinguished moral ideals from specific laws. The moral ideal is the basic moral purpose ordered by the text. While specific legal

\footnotetext{
${ }^{24}$ Ibid., 6-7.

${ }^{25}$ Kurdi, et.al., Hermeneutika al-Qur'an dan Hadis, 72.

${ }^{26}$ Labib Muttaqin, "Aplikasi Teori Double Movement Fazlur Rahman Terhadap Doktrin Kewarisan Islam Klasik," AlManahij: Jurnal Kajian Hukum Islam 7, no. 2 (2013): 200.

${ }^{27}$ Kurdi, et.al., Hermeneutika al-Qur'an dan Hadis, 72-73.
}

provisions are specifically applied. Moral ideal is more appropriate than specific legal provisions. Moral ideals are universal. The Qur'an and the hadith are seen to be elastic and flexible, while specific legalities are more particular. ${ }^{28}$

Rahman's socio-historical approach was a refinement of the concept of asbab an-nuzul formulated by the previous muffasir. The difference lies in the reach of the asbab an-nuzul. In interpreting the text, classical muffasir only included asbab an-nuzul in particular cases to be the background of the decline of the verse. This context is also called the historical context (asbab an-nuzul micro). Rahman also used the historical context (asbab an-nuzul micro) to extended the environmental context (asbab annuzul macro) included the situation of society, customs, institutions to the life in the Arabian peninsula at the time of the descent of the text. ${ }^{29}$

To understand the text fully and comprehensively, Rahman argued that mufassir need to understand their pre-Arabic religion, their social, economic, and political life well and also understand the important role of the Quraysh and the influence of their religious economic power among the Arabs. ${ }^{30}$

\section{Interpret the Hadith of Women's Leadership Failure: Textual versus Contextual}

Textof hadith

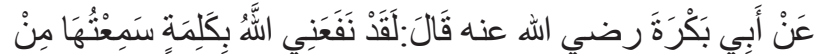

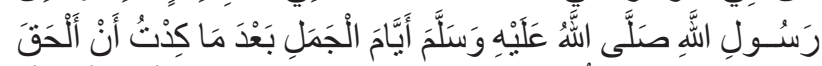

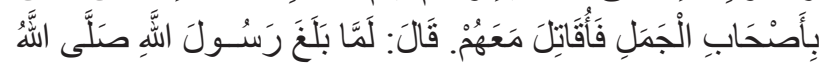

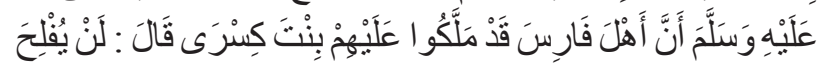

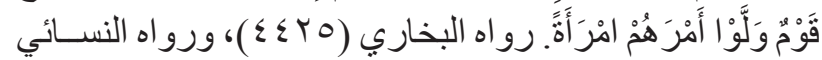

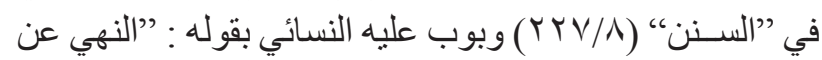

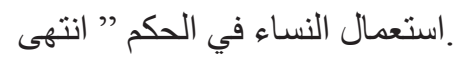
"From Abû Bakrah, he said: Allah has awakened me through the sentences that I heard from Rasul SAW, when I was almost involved in the Jamal (camel). Is when

\footnotetext{
${ }^{28}$ Ibid., 73.

${ }^{29} \mathrm{Abdul}$ Mustaqim, Epistemologi Tafsir Kontemporer, 177.

${ }^{30}$ Ibid., 177.
} 
delivered to the Prophet. that the Persians had adopted Kisra's daughter as their ruler (queen). (At that time) The Prophet said: It will never be a success for a nation ruled by women. "(Narrated by Bukhari). It is also narrated by an-Nasa' $i$ in the book as-Sunan and he included it in the discussion of the prohibition of women's involvement in the realm of judicial power (being a judge).

\section{a. Traditional textualist interpretation}

The textual approach explored the meaning of the text rigidly based on its literal meaning. In this context, the hadith was only understood as is following the editorial text. ${ }^{31}$ This is usually used by scripturalist schools. The textual meaning is considered to be fixed and universal and then applied over time. ${ }^{32}$ The linguistic approach analyzed the textual meaning of language as one of the methods used as a reference by traditional commentators in interpreting the hadith. The word of ${ }^{\text {in }}$ Arabic grammar studies are included in the type of letters that function to negate something in the future (li an-nafyi fi al-mustaqbal). ${ }^{33}$ The word of لَنْ followed by fi'l mudhari' يُنْفِ used in the editorial of the hadith grammatically denotes omission (nafy) applies to the future grammatically fi'l mudhari' besides showing meaning hal (now) mustaqbal (future). ${ }^{34}$ This hadith was also used as a basis by al-Nasa'i as the argument for the prohibition of women from becoming judges. It can be understood textually that the hadith stated society would not be prosperous at any time when surrendering its leadership to a woman including in women's leadership in court.

Based on textual, grammatical analysis, some scholars said that the Prophet's statement

\footnotetext{
${ }^{31}$ Pipin Armita and Jani Arni, "Dinamika Pemahaman Ulama tentang Hadis Dajjal (dari Interpretasi Tekstual Ke Interpretasi Kontekstual)," Jurnal Ushuluddin 25, no. 2 (2017): 214.

${ }^{32}$ Sahiron Syamsuddin, Hermeneutika dan Pengembangan Ulumul Qur'an (Yogyakarta: Pesantren Nawesea Press, 2017), 52.

${ }^{33}$ Fuād Ni'mah, Mulakhkhas Qawāid al-Lughah al-'Arabiyyah, juz 1 (Beirūt: Dār ats-Tsaqāfah al-Islāmiyyah, n.d.), 140.

34، Abd al-Hādi al-Fadli, Mukhtasaru an-Nahwi (Jedah: Dār alSyurūq, 1980), 16.
}

generally applied and at any time, not only to the Persians. According to scholars, all nations led by women will experience failure. This view was implemented by Abdul Qadir Abu Faris who said that what had to be considered as the sound (text) of the hadith which showed general meaning, not consideration of sabab al-wurud or the context of the decline of the hadith, as understood from the rules of fiqh al- 'ibrah bi 'umûm al-lafz la bi khusûs al-sabab. ${ }^{35}$ Thus, othersmufassirsuch as alBaghowi, al-Qadhi ibn Abi Bakr ibn al-'Arabiy, Asy-Syaukani, and Ibn Jarir, argued that it is not permissible for women to become heads of state, court judges, and other public positions. ${ }^{36}$

This hadith by some classical muffasir was then integrated withal-Qur'an verses and other hadith; Q.S. an-Nisa' [9]: 34: men is a leader of women, other hadith that was integrated with Abi Bakrah was the insignificance of women as a leader because of lacking in reason, ${ }^{37}$ same as hadith of Abi Bakrah, ${ }^{38}$ the hadith about women was created from crooked ribs, and women were quite instrumental in serving their husbands. ${ }^{39} \mathrm{It}$ appeared that the interpretation of the sacred text plays a role in the portrayal of women who tend to be biased. ${ }^{40}$ Therefore, women are considered unfeasible to be leaders.

The textual interpretation of the classical mufassir seems to contradict to the Qur'an -

\footnotetext{
35‘ Abd al-Qādir Abū Fāris, al-Nizām al-Siyāsi fì al-Islām, 1984, $182-83$.

${ }^{36}$ Ibn Hajar al-Asqalāni, Fath al-Bāri, juz 8 (Qahirah: Mustafā al-Bābi al-Halab, n.d.), 128. see also: Muhammad ibn Ismāîl al-Sanāni, Subul al-Salām, juz 4 (Bandung: Maktabah Dahlan, n.d.), 123.

${ }^{37}$ Nawir Yuslem, "Kontekstualisasi Pemahaman Hadis," Miqot: Jurnal Ilmu-ilmu Keislaman 34, no. 1 (2010): 9.

${ }^{38}$ Atiyatul Ulya, "Kritik Kualitas Matan Hadis Perempuan Lemah Akalnya Perspektif Salahudin Ibn Ahmad Al-Adlabi," Jurnal Ushuluddin 26, no. 1 (2018): 59.

${ }^{39}$ Muhammad Rikza Muqtada, "Kritik Nalar Hadis Misoginis," Musãwa Jurnal Studi Gender dan Islam 13, no. 2 (2014): 91-92. ${ }^{40}$ Carla Makhlouf Obermeyer, "Islam, Women, and Politics: The Demography of Arab Countries," Population and Development Review 18, no. 1 (1992): 47, https://doi.org/10.2307/1971858. See also: Alfitri, "Women's Rights and Gender Equality Issues In Islamic Law In Indonesia: The Need To Re-Read Women's Status In The Islamic Religious Texts," Mazahib 13, no. 1 (2014): 30 .
} 
equality and justice. The equality and justice agreed upon are noble human beings who are present in God, receive reward or punishment for what they have done, and get the opportunity to become a leader. ${ }^{41}$ In addition, this interpretation also contradicts the current reality which shows that there are many qualified Muslim and nonMuslim women leaders elected as mayors, regents, governors, ministers and even presidents or prime ministers in our country and in other countries in line with the increasing women's education literacy, involvement in various public employment sectors, and an open political system..$^{42}$ The textual understanding of the hadith is not appropriate with the current context; when the hadith is interpreted textually and then the meaning is generalized to the present condition. This interpretation seems to against the social reality and al-Qur'an that carries justice and equality and Islamic teachings salih likulli zaman wa al makan.

The textual meaning happen because mufassir use micro context approach; that is the specific context in the form of language used in the editorial of hadith (matan) and specific wurud asbab to explain why the hadith exists. This approach does not attain the macro context of social settings of the community at the time the narration was narrated. The textual meaning brought up to the present, but the implication seems to be forced to remain in effect at any time

\footnotetext{
${ }^{41}$ Q.S. an-Nahl: 97 which mean: "Whosoever doeth right, whether male or female, and is a believer, him verily we shall quicken with good life, and We shall pay them a recompense in proportion to the best of what they used to do. "The same opportunity to lead as shown in Q.S. at-Taubah verse 71, meaning: "And the believers, men and women, are protecting friends one of another; they enjoin the right and forbid the wrong, and they establish worship and they pay the poor-due, and they obey Allah and His messenger. As for these, Allah will have mercy on them. Lo! Allah is Mighty, Wise."

${ }^{42}$ Susan Blackburn, "Indonesian Women and Political Islam," Journal of Southeast Asian Studies 39, no. 1 (2008): 96. See also: Valentine M. Moghadam dan Fatemeh Haghighatjoo, "Women and Political Leadership in an Authoritarian Context: A Case Study of the Sixth Parliament in the Islamic Republic of Iran," Politics \& Gender 12, no. 01 (Maret 2016): 172, https://doi. org/10.1017/S1743923X15000598.
}

and contrary to the social realities that exist in a democratic society such as in Indonesia.

b. Contextual interpretation with the double movement approach

The double movement hermeneutic contextual approach is to explore the socio-historical background of the time when the hadith text emerged. The assumption is that the text is not autonomous so that the text cannot be understood precisely without considering the micro and macro context. Then the interpreter tries to explore the moral ideal behind the literal meaning of the text. Thus, the interpreter will produce contextualization of the idea of the text without having to get stuck in a text frame that tends to produce a textualist, literalist and scriptualist understanding..$^{43}$ The use of contextual approach aims to get the meaning of the hadith so that it can remain relevant in the present.

As explained in the theoretical framework of double movement hermeneutics, the first step to interpreting the hadith was to explore the historical, social, and political contexts hadith in the form of micro and macro context. The micro context, Abi Bakrah was invited to Jamal war led by a woman, Aisyah. He then refused the invitation because he remembered the words of the Prophet, which means: There will never be a prosperous nation led by women. This hadith was the Prophet's response when he received message that the person appointed as Persian King at that time was a woman. When mufassir stay on micro context, the interpretation up to that meaning and produce bias, this will be generalized until now and understood textually that women would not succeed when they become a leader.

The meaning will be different in the macro context. As Rahman said that the macro context encompasses the environmental context (asbab an-nuzul as macro) includes the situation of social, economic and political life, customs,

\footnotetext{
${ }^{43}$ Abdul Mustaqim, Epistemologi Tafsir Kontemporer, 300-301.
} 
institutions to life in the Arabian Peninsula at the time of the descent of the text. ${ }^{44}$ Based on this theory, this study traced the historical background of the succession of leadership changes to the Persian empire to the reign of the kingdom fell on a woman. The appointment of Buwaran binti Syairawaih bin Kisra bin Barwaiz occurred after the previous king led the Persian empire for 40 years and was then killed. The assassination of the king led to political contestation. It was then the murder of another crown prince; because there were no more crown princes who were male, the political elite appointed Buwaran binti Syairawaih bin Kisra as the king. ${ }^{45}$

Zaitunah Subhan said, this hadith was related to the Prophet's response when giving information about the Persian King (Kisra) who was arrogantly tearing up the letter sent by the Prophet to him. One time King Kisra was killed by his son, it did not stop there the crown prince then killed all his brothers, then the child died of poisoning. Because the male crown prince had been killed, the kingdom was ultimately led by a woman named Buwaran binti Syairawaih bin Kisra. Not long after, this kingdom was destroyed in accordance with the words of the Prophet. According to Subhan this hadith was revealed by the Prophet as a reminder in terms of legal legitimacy and has no legal relevance. ${ }^{46}$

The appointment of women as kings at that time was clearly incompatible with royal traditions that had lasted for generations. Traditions in Persia exhibited that the king's successor was the crown prince male. It can be seen in the lineage of the previous king was male. For instance, King Yazdajard led for 7 years, continued with Balasy bin Fairuz for 4 years then replaced by Qabadz bin Fairuz who ruled for 43 years then continued by Kisra Anu Syarwan 47

\footnotetext{
${ }^{44}$ Abdul Mustaqim, 177.

${ }^{45}$ Iqshari, al-Imāmah al-Siyāsiyyah li al-Mar'ah, Dirāsah Naqdiyyah Haditsiyyah, 199.

${ }^{46}$ Subhan, Al-Qur'an \& Perempuan Menuju Kesetaraan Gender Dalam Penafsiran, 94.
}

years and continued by Hermez 12 years before finally he was killed, then continued by Kisra bin Hermez for 30 years before eventually being killed, continued by his son Syairweh for only a few months, and continued by Ardasyir for 1 year before he was finally killed, then maintained by Syahrayar who was in power for 40 years before eventually he was killed, then continued by Buwaran binti Kisra who was the subject of this hadith, he led for 1 year 4 months later she was dead, then the kingdom was led by his sister Azrmidikhat for 6 months, then the last Persian king to lead was Yasdujard for 20 years and after that the Persian kingdom collapsed. ${ }^{47}$

The appointment of women as kings only took place because there were no male crown prince's left. ${ }^{48}$ This historical-sociological history exhibited the women were not cadres from the beginning became king because the position of women at that time was still subordinate and their rights were still minimal. This condition illustrates the unpreparedness of cadre leaders during the dynastic reign. Buwaran binti Syairawaih eventually became the King even though, according to women's culture was not prepared for it. The condition of Buwaran Binti Syairawaih's unpreparedness as a substitute who had not been cadre as the highest leader from the beginning could be predicted to have difficulty in leading, especially since the kingdom in a conflict between the elites after the previous Raja who ruled for 40 years was killed. Buwaran binti Syairawaih Most likely would fail in continuing his previous leadership due to his inadequate and inadequate internal condition and external conditions where conflicts occur between the royal elite.

It appears that the hadith "It will never be prosperous for a nation led by women" existed in a specific historical-social-political context at that time. Therefore, the hadith must be

\footnotetext{
${ }^{47}$ Iqshari, al-Imāmah al-Siyāsiyyah li al-Mar'ah, Dirāsah Naqdiyyah Haditsiyyah, 197.

${ }^{48}$ Ibid., 203-4.
} 
understood contextually. The textual message of the hadith, women would not be successful when leading cannot be generalized and brought up to the present, mainly if it is applied amid a democratic country like Indonesia. It is due to the success or failure of leadership, both female and male leadership, including in the realm can change (mutaghayyirat), both have the same chance of success and failure in leadership. But the contextual message as the primary objective of the hadith or what Rahman called a moral ideal was still relevant and can be applied today.

It can be concluded that the contextual, which is the moral ideal goal of these traditions include: First, the inability of a person to lead is not caused by his gender but is caused by unpreparedness and incompetence in leading. Second, leadership is not limited to a certain gender. Men or women can be a leader while he/she has the competence to lead and get support from the people. The third is the ineffectiveness of the royal (nation) political system in the succession of leadership change and regeneration of leaders which sometimes causes conflicts. Besides, this system closes opportunities for civilians who are not royal families to become leaders.

The moral ideal extracted from the hadith is relevant used today. It is often found candidates who seem "forced" by the party become leaders. The aim is to gain votes for the party because of the popularity and artistry of the candidates. It could be that the prospective leader previously did not have a track record as a cadre of parties or organizations that have mature leadership insight and experience, when he was chosen as the leader only because of his popularity, it can be ascertained that the primary mission as a leader will not succeed.

The second relevance moral ideal is related to the ability of a leader regardless of gender, which gives an ample opportunity for anyone to become a leader. Nowadays, women leaders have the right leadership competencies to lead a particular institution or region well. For instance,
Tri Risma Harini became Mayor of Surabaya, Susi Pujiastuti became Minister of Maritime Affairs and Fisheries, Sri Mulyani Minister of Finance, and others. The International level is well known Indira Gandi, Margaret Tacher, Srimavo Bandaranaeke, Benazir Butho and Sheikh Hasina Zia as models of the nation's relatively successful leaders. ${ }^{49}$

The ineffectiveness of political dynasties in leadership regeneration relevance is being drawn present. It still often found leaders such as regents, governors, even presidents who proposed their wife, children or siblings to replace positions that have been completed and close the opportunity for other cadres to become successors to the next leadership. If the model of leadership inheritance is still feudal leadership regeneration will be hampered and have an impact on not achieving the primary mission of leadership, namely the welfare of the people to the maximum.

It can be verified that it became irrelevant when the hadith "There will never be a successful nation led by women" was associated with Q.S. an-Nisa': 34. Because the interpretation of Q.S. an-Nisa': 34 according to interpreters such Ali as-Shabuni, Abi Hayyan al-Andalusi, M. Quraish Shihab and others only focused on leadership in the family sector. ${ }^{50}$ Meanwhile, if it looked at the micro context and the macro of the hadith narrated by Abu Bakrah related on the public sector leadership and other misogynistic hadiths such as the hadith which justified that women lack to fit to be leaders. So the hadith was less common sense. If hadith examined from the matan it is not $\underline{s} a \underline{h} \underline{h}$ because its editorial is contrary to the Qur' an verse, other valid hadith, sirah Nabawiyyah, attitude and politeness of the Prophet in speaking. ${ }^{51}$ It can be concluded thatthe

\footnotetext{
${ }^{49}$ Husein Muhammad, Fiqh Perempuan, Refleksi Kiai atas Tafsir Wacana Agama dan Gender (Yogyakarta: Ircisod, 2019), 290.

${ }^{50} \mathrm{M}$. Quraish Shihab, Membumikan al-Qur'an, Fungsi dan Peran Wahyu dalam Kehidupan Masyarakat (Bandung: Mizan Pustaka, 2007), 274.

${ }^{51}$ Atiyatul Ulya, "Kritik Kualitas Matan Hadis Perempuan Lemah Akalnya Perspektif Salahudin Ibn Ahmad Al-Adlabi," 67.
} 
hadith is precisely when it is intertexted with other hadith narrated by al-Bukhari:

قال صلى الله عليه وسلم:إذا ضيعت الأمانة فانتظر الساعة، قال:

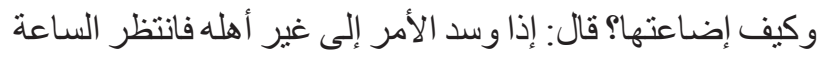
(رواه البخاري)

The Prophet said: if that trust is wasted, then wait for failure to come. Friends say: what is the wasted form of trust? The Prophet said: if given up to someone who is not an expert, then wait for failure.

This hadith implies failure in handling something including the leadership of the president, governors, regents, judges and other public sectors because of unprofessionalism and leadership capabilities, not caused by a particular gender. The message of this hadith can be used to reinforce the previous hadith narrated by Abu Bakrah. The failure of Buwaran binti Kisra in leading his nation was caused his unprofessionalism, the unprofessional attitude in leading alight to anyone, both men and women. Therefore the main message in the hadith is the failure of the leader not because he is a woman or man but because less professional.

\section{Conclusion}

A different approach in interpreting the hadith will bring up a different meaning product. Literal textual approach in understanding the hadith narrated by Abi Bakrah will lead to an understanding that is oriented to the textual knowledge of the hadith. When interpreted textually, the hadith shows that women will never succeed when they become leaders. The textual meanings are no longer relevant to the social conditions of society at this time, especially for Muslim communities who live in democratic countries such as Indonesia that create competent women leaders.

Contextualist approach with double movement hermeneutics involving micro and macro contexts produced contextual hadith meanings that appropriate with the existing social realities and can be applied to the present. With Fazlur Rahman's double movement approach, this study found the moral ideals that are relevant to date. Moral ideal is the success of leadership not because of a specific gender but because of one's readiness and competence to be a leader and supported by a conducive socio-political situation. Failure of a leader may be due to lack of capacity to lead and only prioritize popularity, money, and political dynasties. This kind of leader is the target of the hadith namely the leader has never succeeded to bringbenefit for society, and not related to gender.

\section{References}

Abdullah, M Amin. Islamic Studies di Perguruan Tinggi, Pendekatan IntegratifInterkonektif. Yogyakarta: Pustaka Pelajar, 2012.

Alfitri, Alfitri. “Women's Rights and Gender Equality Issues in Islamic Law in Indonesia: The Need To Re-Read Women's Status In The Islamic Religious Texts." Mazahib 13, no. 1 (2014).

Armita, Pipin, dan Jani Arni. "Dinamika Pemahaman Ulama tentang Hadis Dajjal (dari Interpretasi Tekstual Ke Interpretasi Kontekstual)." Jurnal Ushuluddin 25, no. 2 (2017): 208-220.

Asqalāni, Ibn Hajar al-. Fath al-Bāri, juz 8. Qahirah: Mustafā al-Bābi al-Halab, n.d.

Bay, Kaizal, dan Sri Chalida. "Reinterpretasi Terhadap Pemahaman Hadits-Hadits Tentang Gender Dalam Perspektif Fiqh Al-Hadits." Jurnal Ushuluddin 24, no. 1 (2016): 37-50.

Blackburn, Susan. "Indonesian Women and Political Islam." Journal of Southeast Asian Studies 39, no. 1 (2008): 83-105.

Bukhari, 'Abd Allah Muhammad ibn Isma'il 
al-. Shahih al-Bukhari. Juz 4. Beirut: Dar al-Fikr, t.t.

Fadli, 'Abd al-Hādi al-. Mukhtasaru an-Nahwi. Jedah: Dār al-Syurūq, 1980.

Fāris, 'Abd al-Qādir Abū. al-Nizām al-Siyāsi fî al-Islām, 1984.

Fudhaili, Ahmad. Perempuan di Lembaran Suci, Kritik atas Hadis-Hadis Shahih. Jakarta: Kementerian Agama RI, 2012.

Hamka, Husain. "Kepemimpinan Perempuan dalam Era Modern." Al-Qalam 19, no. 1 (2016): 107-116.

Iqshari, Tsuriyah. al-Imāmah al-Siyāsiyyah li alMar'ah, Dirāsah Naqdiyyah Haditsiyyah. al-Maghrib: Ifriqya asy-Syarq, 2017.

Khoirin, Nur. Telaah Terhadap Otensititas Hadits-Hadist Misogini. Yogyakarta: Kerjasama Mc.Gill Project, Departemen Agama RI, dan IAIN Sunan Kalijaga, 2017.

Kurdi, et.al. Hermeneutika al-Qur'an dan Hadis. Yogyakarta: eLSAQ Press, 2010.

Lajnah Pentashihan Mushaf al-Qur'an. Tafsir al-Qur'an Tematik. Jilid 3. Jakarta: Kamil Pustaka, 2014.

Ma'shumah, Lift Anis. "Teks-teks keislaman dalam kajian feminisme muslim: Telaah metodologis atas pandangan feminis muslim terhadap penciptaan dan kepemimpinan perempuan." Sawwa: Jurnal Studi Gender 7, no. 2 (2012): 67-90.

Moghadam, Valentine M. dan Fatemeh Haghighatjoo. "Women and Political Leadership in an Authoritarian Context: A Case Study of the Sixth Parliament in the Islamic Republic of Iran." Politics \& Gender 12, no. 01 (Maret 2016): 168-97. https://doi.org/10.1017/ S1743923X15000598.
Muhammad, Husein. Fiqh Perempuan, Refleksi Kiai atas Tafsir Wacana Agama dan Gender. Yogyakarta: Ircisod, 2019.

Muqtada, Muhammad Rikza. "Kritik Nalar Hadis Misoginis." Musãwa Jurnal Studi Gender dan Islam 13, no. 2 (2014): 87-98.

Mustaqim, Abdul. Epistemologi Tafsir Kontemporer. Yogyakarta: eLKIS, 2011.

Muttaqin, Labib. “Aplikasi Teori Double Movement Fazlur Rahman Terhadap Doktrin Kewarisan Islam Klasik." AlManahij: Jurnal Kajian Hukum Islam 7, no. 2 (2013): 195-206.

Ni'mah, Fuād. Mulakhkhas Qawāid al-Lughah al-'Arabiyyah, juz 1. Beirūt: Dār atsTsaqāfah al-Islāmiyyah, n.d.

Novianti, Ida. "Dilema kepemimpinan perempuan dalam Islam." Yin Yang 3, no. 2 (2008): 255-261.

Obermeyer, Carla Makhlouf. "Islam, Women, and Politics: The Demography of Arab Countries." Population and Development Review 18, no. 1 (1992): 33-60. https:// doi.org/10.2307/1971858.

Rahman, Fazlur. Islam and Modernity, Transformation of an Intellectual Tradition. Chicago: The University of Chicago Press, 1982.

- Tema-tema Pokok al-Qur'an terj. dari Bahasa Inggris oleh Erfan Nurtawab dan Ahmad Baiquni. Bandung: Mizan, 2017.

al-Sanāni, Muhammad ibn Ismāîl. Subul alSalām, juz 4. Bandung: Maktabah Dahlan, n.d.

Shihab, M. Quraish. Membumikan al-Qur'an, Fungsi dan Peran Wahyu dalam Kehidupan Masyarakat. Bandung: Mizan Pustaka, 2007.

Sholeh, Ahmad Syukri. Metodologi Tafsir AlQur'an Kontemporer dalam Pandangan 
Fazlur Rahman. Jakarta: Gaung Persada Press, 2007.

Subhan, Zaitunah. Al-Qur'an \& Perempuan Menuju Kesetaraan Gender Dalam Penafsiran. Jakarta: Prenanda Media Group, 2015.

Sumantri, Rifki Ahda. "Hermeneutika Al-Qur'an Fazlur Rahman Metode Tafsir Double Movement." Komunika: Jurnal Dakwah dan Komunikasi 7, no. 1 (2013).

Syamsuddin, dkk, Sahiron. Hermeneutika al-Qur'an Mazhab Jogja. Yogyakarta: Islamika, 2003.
Syamsuddin, Sahiron. Hermeneutika dan Pengembangan Ulumul Qur'an. Yogyakarta: Pesantren Nawesea Press, 2017.

Ulya, Atiyatul. "Kritik kualitas matan hadis perempuan lemah akalnya perspektif salahudin Ibn Ahmad Al-Adlabi." Jurnal Ushuluddin 26, no. 1 (2018): 57-68.

Yuslem, Nawir. "Kontekstualisasi Pemahaman Hadis." Miqot: Jurnal Ilmu-ilmu Keislaman 34, no. 1 (2010). 